\title{
Ensuring State-Legal Regulation On The Prevention of Agrarian Raids as a Form of Counteraction to the Offense and as a Mechanism for the Implementation of International Agricultural Cooperation
}

\author{
Victor Beschastnyi ${ }^{1}$
}

\begin{abstract}
:
The tasks of developing international cooperation in the agrarian sphere between Ukraine and the international community, including the European Union, were determined. The existing reasons for the development of small and medium business representatives are analyzed. The updated structure of the object and the subject side - components of agrarian management is determined. The tendency of international development of organic farming is taken into account. The description and practical significance of the appropriateness of securing the terminological understanding of "raider", "peaceful possession of property" with the aim of unification of the norms of the national legislation with the international ones, including the European one, is given. The state-legal regulation on the way of preventing the offense from the standpoint of functioning of state bodies is considered. Due to the comparative method of scientific study, proposals for changes to the current normative and legal framework of Ukraine are determined. There is a distinction and the need to ensure legal protection and protection of the most vulnerable category of subjects. Today, it is the owners of land plots, including owners of land plots (shares), which have been given a land plot for private peasant farming, horticulture, gardening, subsidiary farming. In particular, such protection should be based on positions of economic, social, legal and moral orientation, which defines an integrated and systematic approach. The state authorities should, through their functional duties and through the authority to provide assistance to such economic entities.
\end{abstract}

Keywords: raiding, peaceful possession of property, agrarian sphere, organic farming, state-legal and state-private mechanism, international agrarian cooperation, agrarian raiding, "weapons" institute.

\section{Introduction}

With Ukraine's independence, began the formation of a new form of ownership, namely private, for certain objects was determined. Such objects were previously in state ownership. In connection with such changes, the need was identified and the improvement of a number of regulatory acts. After all, there were changes in the components of social relations, the object and subjective composition and the content of the legal relationship changed. Such changes and further development have resulted in the presence and distribution of private property. It is private property defined as the basis for the implementation of the appropriate types of economic activity. Ownership provides an opportunity not only to form the authorized capital, but also to determine the possibility of obtaining loans for the purpose of further economic development. 
Such changes and definitions also touched upon the issue of private ownership of land plots. Guided by the special characteristics that are inherent peculiar to land plots, as well as the quantitative composition, which is characteristic of Ukraine for the geographical location, it is possible to state the consideration of the widespread use of private property within the category of agricultural land. Thus the question of regulation is defined as agricultural activity in the general form, as well as directly ownership of the land. Such a statement can be explained by the fact that the encroachment on the part of the relevant actors occurs both on legal entities in the field of agriculture and on owners of land plots who also carry out activities in the field of agriculture, but under the legal regime they are in the status of an individual. According to the national legislation of Ukraine, such entities include: individuals who own land plots, including land plots (shares), individuals who provide land for private peasant farming, gardening, gardening. Therefore, it is expedient to determine the legal and regulatory framework for establishing a public-private partnership for each of the abovementioned entities.

The above characterizes the need to take into account the subject structure, as well as the way to ensure their functioning, to identify problematic elements that arise and have both a covert and a widespread character. Among such elements in recent years in Ukraine and the issues of so-called "raider" capture are determined. The aforementioned, one hundred percent characterizes the chosen topic of scientific search, because for Ukraine - agriculture is a priority direction of development at the state level and from the side of the relevant actors. Guided by the fact that the agrarian sphere in Ukraine today is determined by the subsidy industry, the issues of public-private partnership become relevant and necessary for implementation, including on the way of ensuring international cooperation.

\section{Agrarian Raiding as a Form og Violation of the Right of Private Property And the Conduct of Economic Activity.}

The right to private property is understood as the possession, use and disposal of his property at his own discretion, without thereby violating the rights and freedoms of others. Taking into account the need for unification of the norms of national legislation and international it is necessary to take into account also certain positions of the world space.

In accordance with the Protocol to the Convention for the Protection of Human Rights and Fundamental Freedoms (Verkhovna Rada of Ukraine, 1952), it is possible to determine the legal framework by which: "Every natural or legal person has the right to peacefully own his property. No one shall be deprived of his property except in the interests of society and on the terms provided by law and the general principles of international law. However, the foregoing provisions shall in no way restrict the right of the State to enact such laws as it deems necessary to exercise control over the use of property in accordance with common interests or to secure the payment of taxes or other duties or fines" (Verkhovna Rada of Ukraine, 1952). From such a fixed position, the right to peaceful possession of his property is determined. Within the framework of the national legislation of Ukraine, the question is how to understand "peaceful 
possession", since now no position on peaceful possession is defined in any normative legal act of Ukraine.

In order to ensure the correct and uniform use of the norms of law, both national and international, it is necessary to take into account the Decision of the European Court of Human Rights. With regard to the issue of the right to private property, there are court decisions available, and their content analysis provides the opportunity to state that, in accordance with the Convention (Verkhovna Rada of Ukraine, 1950), "the court examines all questions of interpretation and application of the Convention and its protocols only after all national remedies» (Top of the decisions of the ECHR on the protection of real estate, 2018). Consequently, at the international level, it is determined that only after the use of all means of national legal protection, a person may apply for protection to international bodies. In order to implement such a position, at the national level, all positions for the integrated and systematic protection of the right to private property should be clearly defined at the national level.

It is necessary to draw attention to the positions, which stipulate that during the consideration of cases concerning violation of the right of private property, it is necessary to consider: "does the plaintiff have the right of ownership of the property covered by the content of Art. 1; whether there was interference with the peaceful possession of property and the nature of such interference; is there a deprivation of property" (The SCU summed up recommendations for the protection of property rights, 2015). It is also worth taking into account the approach to the terminological examination of property rights. In addition to the position on the term of ownership under the Convention (Verkhovna Rada of Ukraine (1950), it is necessary to take into account the positions of the said time-limit from the side of the European Court of Human Rights. In particular, "the European Court of Human Rights interprets the notion of "property "(property) much wider in the context of Art. 1 The first protocol under "property" understands not only "existing property" (existing possessions), but also a whole range of economic interests (assets). In addition to movable and immovable property, under Art. 1. the first protocol includes, in particular, shares (and not only in terms of their value, but also in terms of the rights to control the enterprise that they provide to the owner), patents, licenses, professional clientele ("good name"), material compensation, ... » (The SCU summed up recommendations for the protection of property rights, 2015).

A land plot is an object which is in the legal regime of the right of private property and which is used for the purpose of economic activity. A certain peculiarity is also determined by the fact that a land plot (share) is the main means for the existence and economic provision of the person or family concerned. An additional feature is that land (units) received only clearly defined persons under national law, including in accordance with a special legislative act (Verkhovna Rada of Ukraine, (1992).

Thus, for today, there are physical persons who independently carry out management on a land plot within the defined legal regime, which does not provide for any registration of the type of management, but the use of such sites is carried out in accordance with legally defined goals, namely: personal peasant farms, gardening, gardening, subsidiary farming. The next group may identify the entities that registered the activity on the land as a type of business. And the most widespread type of economic 
activity is the pursuit of activities by registering a legal entity. And in accordance with the forms of management it is possible to define a diverse structure of such forms of management, such as joint-stock companies, limited liability companies, partnerships with additional liability, agricultural holdings, concerns, consortia, etc. The listed persons can carry out and the farm, having passed the state registration before. In connection with this, and the form of manifestation of agrarian raiding will have different characteristics and versatility of its manifestation.

Any scientific research should be carried out in order to formulate relevant provisions, recommendations for further practical application. On the path to such an achievement, it is necessary to take into account the existing practical situation.

We determine that the issue of raider capture in various forms of its manifestation has a long-standing nature of existence. By studying the situation in June 2019, it is possible to state: "On Saturday, June 1, Bessarabian farmers began to export their grain from the Izmail Elevator. Until recently, he was part of the Agroinvestgroup group of companies, whose leadership went abroad earlier this year. Local lawenforcement agencies actively hinder the actions of farmers" (Police of the Odessa region block the removal of grain from grain elevators by farmers, 2019). On the way to changing the situation with regard to agrarian raids, agrarians turned to this form as a campaign for the purpose of paying attention to the problem and finding ways to solve it. Among the requirements and motivations was defined "to draw the attention of the newly elected president to the problems that blocked the development of the industry leading for the economy for years. Among them is raiding, corruption and arbitrariness of law enforcement and justice, and the unregulated land relations. We sowed, but who will collect this crop, we do not know. Because every year we have a problem with raiders, and only a month left before the harvest. Anti-raider law is not perfect, but then you can make changes to it. For now, he would have saved our situation. And immediately to remove the prosecutor, the leadership of the Ministry of Justice - this gangster grouping, according to farmers" (Farmers urged Zelensky to accelerate the adoption of the anti-raider law and dismiss the leadership of the GPU and the Ministry of Justice, 2019). It is worth noting that such rallies with such requirements are usually a manifestation of democracy, but such slogans, which are a statement of facts, characterized by their negativity, determine only the need for complex and systemic changes that should cover the diversity of spheres and not only economic orientation. In the context of this, agrarians are required to "restart the law enforcement system and protect producers and processors from raiders" (Farmers will ask Zelensky to release Lutsenko and stop raiders, 2019). The mass media also gives examples of raider seizure of the agrarian enterprise of the Prilutsky district of Chernihiv region "KrokoKrZalizBud" (Raiders in the Chernihiv region invaded an agricultural enterprise and beat the leadership, 2019).

Given the prevalence of raider hunts, lawyers also define certain tips-actions, how to withstand raider hobby. So it is defined: "types of raiding differ in the purpose, which put themselves to those who are planning an attack. One of the most common types in the agricultural sector, according to a lawyer, is to harvest and escape. This can be done by double registration of lease agreements. The farm has active lease agreements with owners of land plots, cultivates fields, carries out sowing works. When the harvest 
time comes, there are new treaties on the front of the register that they are the owners of the crop. These people come and gather everything. When agrarians begin to solve the issues of documents - he already loses in time. False executions may also appear, in which the harvest carried out and transferred to a third party for storage. After such a transfer, finding it is unrealistic. Another scheme aimed at taking ownership of the agricultural company and its assets. Through the state or municipal registrar, the riders in the constituent documents change the owners of the enterprise. After the change of founders, operational-general meetings are held, on which the manager changes. With these documents, security riders come to the base of the agribusiness. As long as the real owner understands the situation, criminals can take the harvest and sell the technique. Regarding ways to prevent attacks on a company, an attorney advises you to structure a business into several companies that are not interconnected. It is also necessary to pay attention to the safety of owners of corporate rights and assets and to check their origin. It is necessary to monitor the register of real rights, legal entities and court decisions. Thus, the owner of the company quickly find out if someone has been acting with his company" (Raiding is planned in advance: how to counteract agrarians seizure of land, crops and enterprises, 2019).

A positive direction in the field of the implementation of any kind of economic activity should be attracting foreign investment, respectively; the country must have an investment climate and ensure the security of activities. However, in this context, it is also possible to cite: "Felix Agro LLC with a land bank of 2.3 thousand hectares has 75\% of German investments and works in Volyn since 2006. ... This year, the riders appeared with prosecutorial inquiries and criminal cases. On April 25, 2019, a criminal case was filed under Art. 367 "Service negligence" of the Criminal Code of Ukraine against the village council. Olika, which LLC "Felix Agro" leases these land plots. The raiders demand to acknowledge the illegal lease agreement for unused land between the village council and our farm. At the request of the Kivertsi Division of the Manevich Local Prosecutor's Office, the village council is obliged to provide originals of all land lease agreements, and to create a separate document on the contracts whose term of lease ends this year. According to our data, the pressure from the prosecutor's office is due to the fact that the raiders are her former employees. ... According to the head of the legal department of the security company "Haydamaky", such a scheme is typical for so-called "black" and "gray" raiders. Initially, information is collected on the lease agreements, the validity of which will expire soon. Then, without the owners of land plots, these contracts are forgery: in the column "Lessee" indicate the raider company. Further information is entered into the State register of real rights to real estate with the help of "black" registrars. And while litigation is going on, and this can be delayed for years, raiders successfully process the land (An agribusiness firm with German investments made a raider attack, 2019). Such positions only determine the lack of protection and protection from the part of state bodies, which is not clear and acceptable to international companies, and at the national level, Ukraine should be subject to eradication.

According to the information of the persons who are implementing legislation, it is determined: "According to the General Prosecutor's Office, over 2000 illegal 
seizures of land, harvests, etc. have been recorded during the last 5 years. Every year the trend is growing" (Ukrainian farmers are increasingly becoming victims of raids, 2019).

Murder farm families has become quite common in Ukraine. It directly defines the issues of protection the mechanism for their implementation, and also the question arises about the possibility of identifying raider hijackings, even by killing owners of farms or land (shares) (The name of the murdered farmer from Nikolayev region has become known, 2019; In Vinnytsya killed a family of gardeners, 2019; Another killing of the spouses of farmers happened, 2019; Crafts killed farmer in the Odessa region, 2017; The name of the farmer killed in the Kyiv region has become known, 2019). It should be noted that the type of economic activity is not limited exclusively to the farming sector, but also characteristic for gardening, gardening, personal farming, beekeeping. Accordingly, the subject structure of emerging social relations is increasing, including within raider attacks, hobbies. The isolation of raider attacks and raider hijackings, within the limits of practical comparison, gives grounds for offering to understanding, namely, a raider attack - these are direct actions related to the material appropriation of the object and implemented through the use of weapons, and raider hobbies - actions that contain encroachment on subjective property, subjective property rights and obligations.

In certain areas, appropriate meetings are organized with the participation of representatives of the agrarian sector, authorities, representatives of the National Police of Ukraine, the Prosecutor's Office and the Security Service of Ukraine. So, with the example of the Zaporizhzhya region since 2017: a regional headquarters has been set up to counteract the unlawful takeover and seizure of agricultural enterprises. And among the renewed actions, it is precisely the plunder of those farmers who have recently received funds from the sale of agricultural products. Among the measures to change the situation are identified and the establishment of a "safe village" program, the installation on the streets of video cameras, the need to conclude contracts with the police guard. The practice of signing agreements with the Police of Guard has a common character in the Dnipropetrovsk region, but is limited in Zaporozhye, while attention is drawn to the fact that the police guard should ensure the protection of farms in a compulsory manner without concluding the relevant contracts, explaining this by paying taxes. The key aspect was determining the problems of raidering at the level of not just oblasts, but Ukraine (Attacks on farmers and other agricultural producers have become more frequent in the Zaporizhia region, 2019).

It is these facts that characterize the current practical situation in the agrarian sector. In order to further regulatory regulation, it is necessary to pay attention to the terminological aspect of raider attacks. Indeed, from the correct definition of it, the further possibility of its use depends on the regulation of social relations. In this case, any settlement and direct application takes place within the limits of the fixed definition.

In the scientific doctrine there are different approaches to the direct understanding of "raider". This term was originated in the United Kingdom and was associated with the execution of British warships alone in combat missions to capture trading ships of other states (Raiding in Ukraine is a threat to national security, 2010). According to posted information, according to estimates by experts, the first raider is determined by John Rockefeller, and raider action was to buy shares of their competitors. In the context of this, we can note that this person participated in the 
formation of agrarian policy not only within the limits of one's own country, but also around the world, accordingly it is possible to conclude that attracting raiders in the agrarian sector.

Depending on the scope of the raids and its types, the classification, distinguish between different forms of raiding action. In particular, distinguish black, white, gray raiders, and the implementation of the GreenMale, which is understood as "blocking and obstructing the work of the company as a result of blackmail by small share holders" (Raiding in Ukraine is a threat to national security, 2010). Among ways to seize an enterprise is to distinguish: "purchase of shares; conducting additional issue of shares; bankruptcy; reprivatization; corporate blackmail; dope miss power capture; control over management; fictitious bankruptcy; corruption, and the methodology of raider operations eliminates the systematic nature of such actions: information gathering, attack, PR raid, confrontation between the victim and raider, raider's legalization, completion of the interception of management, seizure results, raider work summary (Raiding in Ukraine is a threat to national security, 2010).

In order to determine the correct and universal term, taking into account all existing positions, types of raiding, etc., it is necessary to state the way in which the relevant authorities consider and define it. Thus, the specialists of the General Prosecutor's Office of Ukraine state that "signs of raiding are illegal actions for the purchase of shares from minority shareholders, disclosure of the data of the owners of shares registers, the issuance of unlawful court decisions (decisions) in cases of resolving corporate conflicts, the unlawful actions of the bodies of the state executive service for execution court decisions (decisions), criminal actions of private security structures and groups of people regarding the seizure of enterprises, etc." (The concept of raiding and its social danger). In line with the position of the Ministry of Internal Affairs of Ukraine, raiding is seen as "the seizure of controversial enterprises, including enforcement of relevant court decisions in favor of one or another owner" (The concept of raiding and its social danger). In cases where the offense is based specifically on the raider's direction, the employees of the Security Service of Ukraine understand: "Illegal seizure of joint-stock companies (including state-owned shares) by outsourced commercial structures through minority shareholders acting in their favor. ... the implementation of illegal schemes of taking over by joint stock companies, accompanied by the seizure of administrative premises and change of management of the company, is a separate form of economic crime"_(The concept of raiding and its social danger).

An additional confirmation that the decision of the raider positions should take place only by complex actions is the position of the scientist in considering the understanding of raider: "as an instrument of capture, which includes a complex of legal, psychological, economic, military-sports techniques and technologies" (R.A. Panasenko Concerning the Criminalization and Interpretation of "Raiders" in Ukraine).

\section{State-legal mechanism on the way of counteraction to agrarian raiding and implementation of international agricultural cooperation}

Formation of modern social relations and their settlement should be carried out from the standpoint of state-legal and public-private partnership. Such an approach 
should determine the formation of the state's main positions and elements that should be the basis for the settlement of the arising relations between the entities at their discretion, on the principle of the so-called "framework". The state should be the main subject that sets the direction of regulation of any relations, forms the economic basis, promotes international development, etc., and the subjects of economic activity are those elements in the structure of the state that contribute to its development and functioning. It is thanks to the established cooperation between them that adequate protection of each will be ensured, and social relations will be within the legal framework.

Currently, the directions of agrarian cooperation between Ukraine and the European Union, as well as other international countries, are quite extensive. Accordingly, the object of social relations, namely, by its expansion, is changing (Piddubna D.S., 2019). It should be noted not only the development of international agricultural cooperation, but also the change in the direction of economic activity, namely the transition to the introduction, implementation and support of organic production or organic farming. This trend on the international level is characterized by the duration and availability of state support, including through a state-legal and publicprivate partnership mechanism.

The essence of the state-legal partnership should consist in the elaboration by the relevant committees and approval by the legislative authority of the necessary and practically weighted normative legal acts that would contribute to the settlement of emerging social relations and correspond to the unification with international norms of law in a certain direction. On the way of such an achievement there should be a very public-private partnership, which, on the one hand, determines the positions to be taken into account in the development of regulatory acts, which will enable the creation of truly necessary regulatory acts, and, on the other, extend the possibility independent regulation of social relations on the part of business entities.

Between researchers in the direction of raids may determine the disclosure of diverse issues. In particular, their works are devoted to the consideration of the protection of the rights of economic entities from the unlawful seizure of property, corporate rights or the establishment of unlawful control over the enterprise (raiding) (Derevianko B.V., 2013); measures to protect business entities from raiders (Turkot O.A., M.Ya. Pylypets, 2018); definition of raider threats within the framework of ensuring economic safety of economic entities (Burbelo O.A., 2015); consideration of innovations in the legislation on protection against raiders (Smolyn H.V., Turkot O.A., 2017); the main directions of prevention of a raider in Ukraine (Mykytchyk A.V., 2013); Consideration of raids in Ukraine and some foreign countries (Tytarenko S.S., 2016); criminal-legal mechanism of counteraction to illegal seizure of legal entities (raider) (Sokolov I.A., 2014).

It is worth noting and highlighting the scientific positions that "the scientific study of criminal law phenomena and institutions is most effective when it occurs using the comparative legal method, especially in cases where a legal phenomenon that has not been unambiguously assessed by representatives of science and practice» (Tytarenko S.S., 2016; Pshypyi R.M., 2014). Directly theoretical issues are considered by scientists and within the limits of theoretical and practical criminological provisions of combating crime in Ukraine (Beschastnyi V.M., 2018). 
Thus, even this list of works and scientific positions form the needs of study and state the lack of unambiguous consideration of raids. In addition, the peculiarity of considering raider attacks within the European Union is that it is carried out precisely from the standpoint of Directive 2004/25 / EC, which regulates issues of stock takeover (Directive 2004/25/EC, 2004). Accordingly, the specificity of the object of social relations is formed.

Within the framework of ensuring the state-legal mechanism of influence on the counteraction to raider attacks, it is possible to define and the bill number 3300 of March 13, 2007 "On Amendments and Additions to Certain Legislative Acts of Ukraine on Establishing Criminal Responsibility for Enterprise Acquisition (Raidership)" define raiding as an order and (or) organization of an attack on an enterprise, institution, organization for the purpose of its capture, which caused a violation of its normal work, as well as an attack on an enterprise, institution, organization, with a view to its closure attitude, committed by an organized group" (The concept of raiding and its social danger). With regard to the said bill it is possible to find certain positions according to which the statement on the addition of the Criminal Code of Ukraine by the following articles: "Art. 205-1 "Forgery of documents submitted for the state registration of a legal entity"; Art. 206-1 "Capture of buildings, structures or other objects of enterprises, institutions, organizations"; Art. 206-2 "Obtaining fictitious rights to the property of enterprises, institutions, organizations". As can be seen from the title of the articles, they are aimed at introducing responsibility for activities that can be considered raider, but at the same time the bill does not contain the concept of "raider" and all derivatives from it" (Fighting Raiding in Ukraine: A New Stage, 2013). However, if you open the draft Law on amendments and additions to certain legislative acts of Ukraine regarding the establishment of criminal liability for the seizure of enterprises (raiding) (Verkhovna Rada of Ukraine, (2007) on the official website of the Verkhovna Rada of Ukraine, we can state that it was withdrawn on June 15, 2007.

The issue of changes in the legal framework for raider attacks, as defined above, will be discussed for a long time. However, this was not reflected in any way directly in normative legal acts. It is possible to state a statement on the adoption of anti-raider laws in September 2016 (Petrenko announced a package of anti-brand laws in September, 2019), and now 2019 is over. Thus, the lack of desire for acceptance generates a lack of normative legal acts.

When studying the regulatory framework, it is necessary to state the fact that the fact of considering the seizure of the enterprises is by the enterprises, but the raider's offense contains a much larger list of objects of the attack, and, accordingly, determines a specific subjective composition.

Referring to the Criminal Code of Ukraine (Verkhovna Rada of Ukraine, 2001), to date, in a modified form, but in some resemblance, contains certain articles. However, their inclusion was based on other normative legal acts, namely, the Law of Ukraine "On Amendments to Certain Legislative Acts of Ukraine on Improving the Legal Regulation of the Activities of Legal Entities and Individual Entrepreneurs" (Verkhovna Rada of Ukraine, 2013) and the Law of Ukraine "On Amendments to the Law of Ukraine" On State Registration of Legal Entities and Individual Entrepreneurs" and some other legislative acts of Ukraine regarding the decentralization of powers on the state 
registration of legal entities, individuals-under entrepreneurs and community groups" (Verkhovna Rada of Ukraine, 2015).

In any case, in the case of raids, the perpetrators must be held accountable, including to the criminal. That is why it is expedient to determine and valid the positions of the Criminal Code of Ukraine, which may lead to the perpetrators to be prosecuted. Although this normative act does not include a direct definition of "raider", which is also mentioned at the level of specialists (National Police: The notion of raiding is still not defined by law, 2016), for a long time there was a position that determined that positions of raider hobbies should be considered under the section of the Criminal Code of Ukraine, which identifies crimes against property. And among the researchers there was an understanding of raider attacks as "the seizure of someone else's property, combined with corruption in the courts and law-enforcement agencies, naturally causes society's indignation and therefore requires legal assessment from the part of law enforcement agencies" (R.A. Panasenko Concerning the Criminalization and Interpretation of "Raiders" in Ukraine). Certainly, raiding involves encroachment on private property, but any decision to prosecute must be based on existing rules of law. Consequently, the issue of prosecution is based on the current norms of law, as defined by the Criminal Code of Ukraine. If it is to be considered within the framework of the code, it is possible to state that, in fact, Chapter VI of the property offense, which covers such offenses as theft, robbery, robbery, abduction of water, electric or thermal energy through its unauthorized use, extortion, fraud, is actually provided for today, appropriation, loss of or possession of property by way of abuse of office, causing property damage by fraud or abuse of trust, misappropriation of a person found or alien property, it was deliberately destroyed or damaged by property, intentional damage to electric energy objects, the threat of destruction of property, negligent destruction or damage to property, violation of obligations regarding property protection, unauthorized occupation of land and unauthorized construction, acquisition, receipt, storage or sale of property obtained by criminal means (Verkhovna Rada of Ukraine, (2001). From the envisaged rules of law, it is really very difficult to subject exactly agrarian raids, which may have different character of their manifestation, to the criminal characterization of certain articles. Only in certain positions, it may be possible to apply certain norms, but they will not be 100 percent use, but within the boundary or analogy. A certain application is characterized for Article 197-1 concerning the unauthorized occupation of a land plot. In cases where a threat to the destruction of property occurs as a result of raider attacks, it is possible to speak of Article 195 of the Criminal Code of Ukraine, but raider attacks are rarely determined by the threat, mainly, it will be the destruction of property, which accordingly does not provide grounds for application of this article. Just as raider action is still a deliberate, planned action, in the case of deliberate destruction or damage to property, it is possible to incriminate article 194 of the Criminal Code of Ukraine. All other types of identified offenses may also be used within raider activities, but only in partial positions.

Further, within the limits of section VII of the Criminal Code of Ukraine, crimes in the sphere of economic activity, the following offenses are defined: manufacturing, storage, acquisition, transportation, forwarding, import into Ukraine for use in the sale of goods, sales or sale of counterfeit money, government securities, tickets of the state lottery, stamps of excise tax or holographic protective elements; illegal actions with 
transfer documents, payment cards and other means of access to bank accounts, electronic money, equipment for their production; smuggling; moving through the customs border of Ukraine outside the customs control or concealing from the customs control timber or lumber of valuable and rare breeds of trees, unprocessed timber, as well as other timber products banned for export outside the customs territory of Ukraine; Illicit circulation of disks for laser reading systems, matrices, equipment and raw materials for their production; illegal manufacture, storage, sale or transportation for the purpose of selling excisable goods; fake entrepreneurship; forgery of documents submitted for the state registration of a legal entity and sole proprietors; counteracting legitimate economic activity; unlawful seizure of property of an enterprise, institution, organization; bringing to bankruptcy; falsification of financial documents and financial institution reporting, concealment of insolvency of a financial institution or grounds for revoking (canceling) a license of a financial institution; fraud with financial resources; manipulation in the stock market; forgery of documents submitted for registration of securities issue; violation of the procedure for keeping the register of holders of registered securities; intentional introduction into the market of Ukraine (release to the market of Ukraine) of dangerous products; illegal use of the mark for goods and services, trade name, qualified indication of the origin of the goods; illegal collection in order to use or use information constituting commercial or banking secrets; disclosure of commercial or banking secrecy; illegal use of insider information; concealing information about the activities of the issuer; illegal privatization of state and communal property (Verkhovna Rada of Ukraine, (2001).

Certainly, the existing list of offenses refers to those relations that may be encountered during raider attacks, but we note the fact that only partial actions, as elements of raiding, are possible to apply. That is, if a collection of information took place on the basis of which the enterprise was further seized, we will determine the person's liability for the collection of information or for seizing the enterprise. That is why this kind of characterizes the absence of a specific article that would include a comprehensive description of the offense within the framework of raider action. I am convinced that this should be subjected to eradication by developing an appropriate draft law and amending the Criminal Code of Ukraine. Such a position is also determined at the level of the employees of the Main Investigation Department of the National Police of Ukraine by stating that "in the current Criminal Code of Ukraine there are a number of articles that only to some extent cover the composition of such an offense as the raider capture of the enterprise" (National Police: The notion of raiding is still not defined by law, 2016). Accepting this position, we determine that in the vast majority, raider capture is considered within the capture of the enterprise, which is not justified and does not meet the latest practical requirements.

Regarding the direct activity of the anti-trader headquarters, it is possible to determine their creation in 2017 on the initiative of the Ministry of Justice of Ukraine at the bases of regional state administrations, as well as the inclusion in their membership of representatives of the regional state administration, the Main Territorial Department of Justice, the Regional Directorate of the National Police, the State Geocodraw, the owners or tenants of the land sites According to the results of their activities, they determine: "In 2017, we received 4794 complaints, in 2018 - 3718, then in mid-April 
2019 - 564 complaints about the actions of raiders" (Agrarian raiding Five meals before the intercessor of the Ministry of Justice). Although there is a statement of the activity of the anti-Jewish headquarters, the statistics of the received appeals are recorded, however, it is never determined by what normative-legal act determines their functioning. It is also envisaged a certain procedure for treatment, namely: the victim with a complaint appeals to the regional administration; On the basis of the appeal, representatives of all bodies are gathered, which takes place within one day to one week and a direct meeting of such a headquarters is taking place. If the situation remains unresolved, the victim will continue to submit a complaint to the KLA in the field of state registration under the Ministry of Justice of Ukraine, which should be considered within 30 days, that is, within generally defined terms. And a note is made that, if necessary, the review period can be extended to 45 days. Between the possibilities of influence on raider action is determined only administrative responsibility within the temporary blocking of access to registers (Agrarian raiding Five meals before the intercessor of the Ministry of Justice).

Regarding the activity of the Anti-Breeding Commission of the Ministry of Justice of Ukraine, it is possible to determine its work on the consideration of complaints in the field of state registration. In particular, in the period of 2017 - "226 land complaints, 215 - in respect of immovable property, 83 - in relation to the registration of legal entities and individual entrepreneurs" (The anti-trader commission of the Ministry of Justice over 10 months of this year satisfied more than half a thousand complaints, 2017). At the same time, the activity of any body created should be determined solely by the developed regulatory framework. In connection with this, it is necessary to subject to the statement the Order of the Ministry of Justice of Ukraine No. 37/5 dated January 12, 2016 "On the Activity of the Commission on the Review of Complaints in the Field of State Registration and the Commission on Accreditation of State Registration and Monitoring Substances requirements for accreditation requirements" (Verkhovna Rada of Ukraine, 2016). In accordance with it is determined that the Commission is a permanent collegial advisory body under the Ministry of Justice of Ukraine, and also stipulates that the decision of the commission is drawn up by a conclusion. Before the conclusion, certain requirements and positions to be included are defined. Among such positions it is possible to determine: information on the necessity of drawing up protocols on administrative offenses, the responsibility for which is provided for in paragraphs 1-5 of Article 166-11 and Article 166-23 of the Code of Ukraine on Administrative Offenses; information about the decision / registration actions subject to cancellation, as well as about the actions to be performed in connection with the cancellation of the decision / registration action or in connection with the recognition of the impugned actions or inaction unlawful, and about the subject that will be do the following. Such legal consolidation determines the use of an administrative type of liability, as well as only from the point of view of the violation of the state register. These positions are rather narrow and only for a specific object, which does not constitute coverage of all possible objects of a raider attack. Accordingly, the activity of the Antibride Commission does not necessarily mean the resolution of completely problematic aspects. In addition, we pay attention to its official status, namely, a collegial advisory body that forms a position on which decisions are not binding. Taken together, the said definition determines the need, nevertheless, to create a comprehensive and effective 
body in the field of providing protection and protection in the field of offenses in the agrarian sector.

The question of the existence of the facts of abuse of official position on the part of employees of the State Service of Ukraine on Geodesy, Cartography and Cadastre is devoted to practical situations. In particular, the continued refusal of the owner of the farm in the continuation of the lease is motivated by the lack of an agrochemical passport and other reasons (The farmer from Poltava region managed to win his land in the State Service of Ukraine for geodesy, cartography and cadastre, 2019).

In the future, it may be noted that in 2010, the relevant structural units of state executive bodies that promote protection against raider attacks were noted, however, in 2019, raiding has not decreased. In particular, it was a question of the following system of anti-raider systems:

- Public organization "Anti-Breeding Union of Entrepreneurs of Ukraine";

- Ukrainian National Committee of the International Chamber of Commerce;

- The Interdepartmental Commission on combating illegal abstraction and seizure of enterprises under the Cabinet of Ministers of Ukraine, which includes representatives of the Ministry of Internal Affairs of Ukraine, the Security Service of Ukraine, the Ministries of Justice, Economy and Finance, the State Agency for Investments and Innovations, the Union of Industrialists and Entrepreneurs and the Chamber of Commerce and Industry, the Chamber of Commerce, the State Committee for Entrepreneurship, the Prosecutor General's Office, the State Property Fund of Ukraine);

- Office for combating commercial crime and raiding (using the recommendations of international organizations in the fight against raiding);

- Working groups on counteraction to unlawful absorption and seizure of enterprises at regional state administrations (Raiding in Ukraine is a threat to national security, 2010).

On the way to prevent raider attacks it is determined and expediency of the introduction of an electronic database system, namely, monitoring of land relations, which should include fully information on land plots (Price, raiding, cadastre, bargaining, gender: what else can be found in the database on land relations, 2018). However, such consolidation determines only the direction of encroachment on private property and the appropriation of another's right, but it is necessary to determine that the specified element is not of an exceptional nature, and therefore it will not be a panacea for a $100 \%$ fight against raider attacks.

Thus, the above positions clearly define the various directions that need to be refined in order to combat such an offense in the agrarian sector as a raider. The way of overcoming it must be determined by the fact of international cooperation between Ukraine and various international organizations. In particular, "the project of the Food and Agriculture Organization of the United Nations (FAO) will support Ukraine in establishing a systematic and coordinated approach to providing agricultural advisory services" (Ukraine will develop a sustainable model of advisory services, 2019). With such a common approach on the part of Ukraine and an international organization, taking into account the support of small and medium business entities, it is extremely important to protect and protect against them, including from raider hijackings.

In the future, it is possible to identify the economic side in the agrarian sphere, for which the probability of raider action should be reduced to the maximum. Such 
economic support and assistance takes place at the international level through the implementation of investment policy. In particular, "The Board of Directors of the World Bank approved a decision to grant a loan of \$200 million. USA for implementation of the "Program for accelerating private investment in agriculture", which was established with the purpose of expanding the opportunities of small and medium enterprises in the agrarian sector of Ukraine" (The World Bank will provide Ukraine with a loan of $\$ 200$ million USA investment in agriculture, 2019).

Development of any branch of economic activity in order to ensure the country's socioeconomic stability, it is usually advisable to support the development and development of small and medium-sized entities, including agricultural activities. About the appropriate level in this regard in Ukraine, there are currently no grounds for assertion. In the way of justification of expediency of such support it is possible to bring and choose the international position-tendency. Its essence lies in the fact that family farms have emerged from the "Food and Agriculture Organization (FAO) and International Fund for Agricultural Development (IFAD)", especially in developing countries. ... Family farms make over $90 \%$ of all farms in the world and produce $80 \%$ of food. They are key to sustainable development, including the elimination of hunger and all forms of malnutrition" (The main strategy of the UN for the next 10 years is the family farms, 2019).

For Ukraine, today, other positions regarding European cooperation are well known. As an example, the Ministry of Agrarian Policy and Food of Ukraine in accordance with the European Union project SAFRI carries out nationwide information activity "State support for the development of farms and agricultural service cooperatives in 2019" (The Ministry of Agrarian Policy together with the EU Project is conducting a broad information campaign on state support to farmers, 2019).

The above-mentioned forms a positive vector, but given the European support for various areas of state support, the development of small and medium-sized businesses, it is necessary to talk about the practical non-implementation of such areas in Ukraine. This position is explained by the support of large business entities, the so-called agro-firms. According to the national legislation, it is alleged that owners of land plots, including land plots (shares), can receive state support, but in practice, their receipt becomes a rather significant problem, which gives grounds for confirmation of inconsistency and low level of responsibility on the part of civil servants., who make decisions on whether or not to provide support from the state side. Thus, small and medium business entities are not able to exercise the right to protection and protection, even from the point of view of state support. In addition, such entities, due to the inadequate pricing policy for agricultural raw materials and products, because of the lack of a free international trading market, through a cost depreciation fund, etc., can not provide themselves with the conclusion of an agreement to protect against raiders. This situation of actors creates a fact of victimization and a simplified field for raiders. In order to eliminate such a situation, to ensure compliance with international trends, to ensure the provision of economic and social development in the country, Ukraine faces a number of tasks in this direction.

We believe that such projects really are an element of support of the international level of the national business entity, but believe that activities in the agrarian 
sector must be deduced from the standpoint of independence and the success of the activity depends solely on the actions of the subject. The state should only provide normal conditions for any chosen type of activity. This assistance should consist of the qualitative and necessary regulatory support, promotion of the opening of international markets, reduction of requirements during customs clearance, introduction of moderate taxes and fees, provision by the state through the activities of the relevant bodies of the system of $100 \%$ protection and protection, including through the activities of the structural units of the National Police of Ukraine. Also, international cooperation should be ensured on the part of the state in the part of confirmatory, permissive documents. This is especially characteristic of the agrarian sphere, as we can realize the raw material or products as traditional, ecologically clean, organic. In international markets, such implementation is carried out within the framework of the availability of relevant supporting documents. In Ukraine, the relevant structures that may define such documents, as well as the documents themselves do not find their definition on the form, content, etc., are not currently developed in Ukraine, respectively, the subject of economic activity faces a number of barriers or so-called non-compliance with international requirements. But such requirements are envisaged in relevant international, European conventions, directives, recommendations, regulations, etc. Guided by the European integration course of Ukraine, the national regulatory framework must be subjected to the process of unification, that is, bringing to conformity, terminological unity in the understanding of national normative legal acts and international, including European ones. It is such a duty - the state's duty.

Additional confirmation is also taken by the measures of the Verkhovna Rada of Ukraine Committee on Agrarian Policy and Land Relations through the implementation of the project "support to the Implementation of Agricultural and Food Policy in Ukraine" for holding discussions, training seminars in the direction of "small forms of management as a basis for sustainable rural development in in the context of the implementation of the Association Agreement between Ukraine and the European Union". It is worth noting the issues that are raised to the discussion and we note the positive direction of their discussion. In particular: "the issue of the problems of taxation of small forms of farming in agriculture and their impact on sustainable rural development; Implementation of the tax legislation for small forms of management in the member states of the European Union to the legislation of Ukraine in terms of their legal identification; taxation and tax preferences for small agricultural producers and selfemployed agricultural producers in the European Union on the basis of the experience of Germany, Serbia and the Western Balkans, etc.» (The Committee on Agrarian Policy and Land Relations held a committee hearing on "Small forms of management as a basis for sustainable rural development in the context of the implementation of the Association Agreement between Ukraine and the European Union, 2019).

The study of the meaningful understanding of the term "raider" provides grounds for confirming a number of positions. First of all, raiding is an offense. Secondly, raider attacks can be manifested in fairly common forms. Thirdly, it is expedient to distinguish between general raiding and its distribution by type, among which to determine agrarian raiding, depending on the sphere of economic activity. For committing an offense in the form of a raid can incur liability, which is implemented 
within the civil, economic, administrative and criminal liability. Since the most severe of all these types of responsibilities is criminal, it is necessary to indicate the existing positions regarding the signs of criminal raiding in Ukraine. In particular: "the organized nature of the raider activity; providing a criminal result by committing a number of unlawful criminal acts (falsification of documents, bribery, the use of physical and mental violence, etc.), united by the purpose of taking possession of another's property; involvement in raider attacks of corrupt representatives of the authorities and law enforcement agencies; use of unlawful court decisions for legal cover of a raider attack and obtaining the possibility of ordering someone else's property; Extremely high profitability of raider activity" (The concept of raiding and its social danger). Thus, raiding directly concerns the issue of protection and preservation of property. Accordingly, if criminal liability is to be considered, it is necessary to refer to the Criminal Code of Ukraine (Verkhovna Rada of Ukraine, (2001), which does not define a specific article, which would regulate it. Instead, in order to solve practical situations, articles that relate to property are used.

In addition, when developing appropriate changes to define the concept of "raider" in order to further ensure public-legal and public-private partnership, judicial positions must also be taken into account: "in today's conditions, when domestic legislation in the field of property relations regulation can not be considered perfectly perfect, the courts and unified judicial practice play an important role in ensuring the protection of property rights. Interpretation and, as a consequence, the application by the courts of Ukraine of the national legal rules in the relevant sphere must be in line with the principles of peaceful possession of the property laid down in art. 1 of the First Protocol, but is organically combined with reasonable (adequate, balanced, justified) application of the relevant decisions of the ECHR in order that the method of interpretation and application of domestic law by the court would lead to the consequences of a dispute that is compatible with the principles of the Convention" (The SCU summed up recommendations for the protection of property rights, 2015).

\section{Conclusions}

1. On the path of European integration of Ukraine and in connection with the implementation of the unification of the national legislation with the European, in order to simplify and clearly use the legal acts, the legislative body of Ukraine determined the expediency to develop and introduce changes in terms of the terminological understanding of "property", which has a different understanding today according to the Civil Code of Ukraine, the Criminal Code of Ukraine, the Code of Ukraine on Administrative Offenses and other normative and legal acts, "peaceful possession of the ways ohm";

2. Taking into account the judicial practice of the judgments given by the European Court of Human Rights and the characteristic signs of raiding, the formation of updated entities is determined, as well as the specific composition of the relevant objects is formed;

3. Based on the judgments of the European Court of Human Rights, it is advisable to carry out a scientific and practical study of the understanding of the right to private 
property and to modify it in terms of the relation of content understanding, namely, the rights of private property and property. After all, the property itself is determined within the framework of review of private property, in the conviction of the judges of the European Court of Human Rights, which is reflected in their decisions. Guided by the definitions of private property and property, which today exists at the level of national legislation, it can be argued that the distinction between them is meaningful and if within the generally accepted positions regarding the understanding of "property" it is possible to determine the similarity with the stated position of the European Court of Human Rights, in the part of consideration of private property - at the national level, they are considered as a form of ownership. In addition, we can state that there is no clear distinction in national legislation regarding "property", "things", "personal non-property rights", "intellectual property rights". In some cases, the indicated terms are as similar to each other, others do not. Thus, this part needs further doctrinal study;

4. Classification of raider formation also forms part of the objective composition of agrarian raiding, in particular: the right of private property, the right to receive income, lost profits, land, fruits, berries, property, things, crops, personal vehicles, vehicles agricultural land, household buildings and residential buildings, money, bank deposits, life and health, the right to economic activity, including entrepreneurial activity, the right to a family, the right to life and health of family members, pr t to free correspondence, telephone calls, cybersecurity;

5. Subjects within the framework of agrarian raiding, which may be potential for encroachment, may be presented as natural persons to land owners, natural persons, owners of land parcels (units), individuals engaged in entrepreneurial activity, and legal entities engaged in economic activities activity in accordance with the defined forms of management; and among subjects involved in the implementation of agrarian raiding is directly the subjects carrying out the raider seizure and those who provide assistance, including representatives of the state register, the National Police of Ukraine, state and private notaries, lawyers or persons providing legal assistance (within the framework of legal counseling and legal support), judges, employees of the executive service; employees of district state administrations and local self-government bodies, prosecutors;

6. Provision of legal protection should be exposed not only to owners but also producers and processors, which is a reflection of the practical situation existing in Ukraine, is a pledge to international cooperation and compliance with the general legal principles in the field of protection of the rights of individuals and the conduct of economic activity;

7. The investment policy should be determined exclusively at the state level and have comprehensive support in its implementation, which will facilitate international trade and, in general, agrarian cooperation;

8. Proposed to the delineation and terminology of understanding: raider attack - is the direct actions associated with the material appropriation of the object and is realized through the use of weapons, and raider hijacking - acts that encroach on the attack as a subjective property, subjective property rights and obligations;

9. Attention was paid to the need for consolidation of positions on which the police should provide services in the part of realization of protection of collection and direct sale of agricultural raw materials of owners of land plots, including owners of land lots 
(shares) obligatory without the conclusion of corresponding agreements. Taking into account that at present the police guard acts as a structural subdivision of the National Police of Ukraine and is an element of the implementation of public-private partnership, in order to implement this direction, there is a need for regulatory approval of renewed authority and a partial change in the structural functionality of the police guard.

10. Taking into account the ramified objective and subjective structure of offenses during raids, international experience and requirements, it is expedient to amend the Criminal Code of Ukraine in the framework of the inclusion of a new article "Violations of the peaceful possession of property", with the understanding to be clearly defined peaceful possession of property, property, and during the formation of concepts, all positions regarding signs of raiding are taken into account.

\section{References}

Verkhovna Rada of Ukraine (1952). Protocol to the Convention for the Protection of Human Rights and Fundamental Freedoms. Available from: https://zakon.rada.gov.ua/laws/show/994 535?lang=uk [Accessed 23.05.2019].

Verkhovna Rada of Ukraine (1950). Convention on the Rights of the People and Fundamental Freedoms. Available from: https://zakon.rada.gov.ua/laws/show/995_004 [Accessed 23.05.2019].

Top of the decisions of the ECHR on the protection of real estate (2018). Available from: http://yurgazeta.com/publications/practice/neruhomist-ta-budivnictvo/top-rishen-espl-shchodo-zahistu-neruhomogomayna.html). [Accessed 23.05.2019].

The SCU summed up recommendations for the protection of property rights (2015). Available from: https://zib.com.ua/ua/print/120218u_verhovnomu_sudi_pidsumuvali_rekomendacii_schodo_zahistu_pr.html. [Accessed 23.05.2019].

Verkhovna Rada of Ukraine (1992). About collectively hospitality. Available from: https://zakon.rada.gov.ua/laws/show/2114-12. [Accessed 23.05.2019].

Police of the Odessa region block the removal of grain from grain elevators by farmers (2019). Available from:

https://agronews.ua/node/131606?fbclid=IwAR2GaVstma6vdvhbLFXeHTScyzjMTV5qhbWiB6fC9dCFqR4 rm4v4WS2uyOE). [Accessed 23.05.2019].

Farmers urged Zelensky to accelerate the adoption of the anti-raider law and dismiss the leadership of the GPU and the Ministry of Justice (2019). Available from: https://agronews.ua/node/131328?fbclid=IwAR1OEgdZvy_uvHkNedNEMZy52hLXRIFC_X8e4G1O9sM Ujmr9NbaCa5ym1is). [Accessed 23.05.2019].

Farmers will ask Zelensky to release Lutsenko and stop raiders (2019). Available from: https://agronews.ua/node/131227?fbclid=IwAR2210xCvpaMU2FmqlBbNJE4znUxF6Sabu-6r_dqTy9YEJ4BWBOYB-g5oA). [Accessed 23.05.2019].

Raiders in the Chernihiv region invaded an agricultural enterprise and beat the leadership (2019). Available from: https://zernovik.com/news/v-chernigivskij-oblasti-rejderi-vderlis-na-silskogospodarske-pidpriiemstvota-pobili-

kerivnictvo/?fbclid=IwAR0z6Ga9JvqGQT0gLHANHQ5vr6sAYQ65X8HilZZDBYIpVS5qpZXYK1Zi4FI). [Accessed 23.05.2019].

Raiding is planned in advance: how to counteract agrarians seizure of land, crops and enterprises (2019). Available

from: https://agronews.ua/node/130288?fbclid=IwAR3m9o_MZjX_8WUda5sljWvbOSgHPvnGMi8cLaQFJ0AS4v ifpK3h3Po_W8I. [Accessed 23.05.2019].

An agribusiness firm with German investments made a raider attack (2019). Available from: https://www.growhow.in.ua/na-ahrofirmu-z-nimets-kymy-investytsiiamy-zdiysneno-reyders-kyyzamakh/?fbclid=IwAR2qKMqdc4fSO7T9mPjHRXM2ojkInxYpgYwLS2xRVE4b63u6VXx-fLIwvmQ). [Accessed 23.05.2019].

The name of the murdered farmer from Nikolayev region has become known (2019). Available from: https://kurkul.com/news/15601-stalo-vidomo-prizvische-vbitogo-fermera-z- 
mikolavivschini?fbclid=IwAR2O6spnuJeAxEkcAWiRhaH1R4PN7HnQ24PGTcGEVCAFW1bmBuSj43s8Z Go. [Accessed 23.05.2019].

In Vinnytsya killed a family of gardeners (2019). Available from: https://agronews.ua/node/128666?fbclid=IwAR071JefmWvAnGzwFocLv1L9bItnTs8arUSWBDOdJoYY9 MWGqzcKwlyfEKM. [Accessed 23.05.2019].

Another killing of the spouses of farmers happened (2019). Available from: https://kurkul.com/news/15591stalosya-chergove-vbivstvo-podrujiya-fermeriv. [Accessed 23.05.2019].

Crafts killed farmer in the Odessa region (2017). Available from: https://kurkul.com/news/9987-kradivi-ubilifermera-na-odeschini. [Accessed 23.05.2019].

The name of the farmer killed in the Kyiv region has become known (2019). Available from: https://kurkul.com/news/15224-stalo-vidomo-imya-vbitogo-na-kiyivschini-fermera. [Accessed 23.05.2019].

Attacks on farmers and other agricultural producers have become more frequent in the Zaporizhia region (2019). Available from: http://iz.com.ua/zaporoje/v-zaporozhskuyu-oblast-vernulis-lihie-90-e-grabiteli-vbalaklavah-primenyayut-payalniki-iutyugi?fbclid=IwAR04_rzCaQFPh5IvUpwqcOg4ZdMjnCZiWq0pQ1AUj8xcc0mMhEPbJbeRTsA. [Accessed 23.05.2019].

Raiding in Ukraine is a threat to national security (2010). Available from: http://veche.kiev.ua/journal/2105/). [Accessed 24.05.2019].

The concept of raiding and its social danger. Available from: http://www.pozov.com.ua/ua/rejderstvo ua.html. [Accessed 24.05.2019].

R.A. Panasenko Concerning the Criminalization and Interpretation of "Raiders" in Ukraine. Available from: http://ukrainianpravo.narod.ru/index/0-3. [Accessed 24.05.2019].

Piddubna D.S. (2019). Updated objects of organic farming as elements of further legal regulation. Actual problems of domestic jurisprudence No. 1. 2019. 91-96.

Derevianko B.V. (2013). Legal regulation of the protection of the rights of economic entities: a teacher. Manual. Ministry of Internal Affairs of Ukraine, Donetsk Law Institute. Donetsk: Publishing House "Kalmius", 2013. 94-117.

Turkot O.A., M.Ya. Pylypets (2018). On the measures of management from raiders Scientific herald of Lviv State University of Internal Affairs. Legal series. Editor RI Blessed Lvov: LvDUVS, 2018. Vip. $135-143$.

Burbelo O.A. (2015). Raid threats and economic security of business entities. Bulletin of the Lugansk State University of Internal Affairs named after E.O. Didorenka Issue \# 3 (71). Sumy. 2015. 221-233.

Smolyn H.V., Turkot O.A. (2017). Innovations in the legislation on protection against raiders Scientific herald of Lviv State University of Internal Affairs. Legal series. Editor-in-chief R.I., Balagut. Lvov: LvDUVS, 2017. Vip. 1. 150-158.

Mykytchyk A.V. (2013). Main directions of prevention of raider attacks in Ukraine. Scientific Herald of the National Academy of Internal Affairs, No. 3, 2013. 217-222.

Tytarenko S.S. (2016). "Raiding" in Ukraine and some foreign countries: a comparative view of the economic and legal phenomenon. Comparative and analytical right. №5 2016. Available from: http://www.pap.in.ua/5_2016/82.pdf. [Accessed 24.05.2019].

Sokolov I.A. (2014). The state and development of the criminal law mechanism to counter the unlawful seizure of legal entities (raiders): diss. ... Cand. legal Sciences: 12.00.08. M., 2014. 199.

Pshypyi R.M. (2014). Comparative characteristics of criminal law with a blanket form of disposition on the legislation of Russia and Germany (at the premier of criminal acts in the sphere of economic activity). Crown Law: Strategy and Development in the XXI Century: materials of the International Scientific and Practical Conference. Moscow. January 30-31. 2014. 135-141.

Beschastnyi V.M. (2018). Theory and practice of criminological support for combating crime in Ukraine. Author's abstract to get sciences Doctor of Science of Law. Kharkiv. 2018. 33.

Directive 2004/25/EC (2004). Directive 2004/25/EC of the European Parliament and of the Council of 21 April 2004 on takeover bids. Available from: https://eur-lex.europa.eu/legalcontent/EN/TXT/?uri=celex\%3A32004L0025). [Accessed 26.05.2019].

Fighting Raiding in Ukraine: A New Stage (2013). Available from: http://yurgazeta.com/publications/actual/borotba-z-reyderstvom-v-ukrayini-noviy-etap.html). [Accessed 27.05.2019].

Verkhovna Rada of Ukraine (2007). Draft Law on Amendments and Additions to Certain Legislative Acts of Ukraine on Establishing Criminal Responsibility for Enterprise Acquisition (Raidership). Available from: http://w1.c1.rada.gov.ua/pls/zweb2/webproc4_2?id=\&pf3516=3300\&skl=6. [Accessed 27.05.2019]. 
Petrenko announced a package of anti-brand laws in September (2019). Available from: https://www.ukrinform.ua/rubric-economy/2070835-petrenko-anonsuvav-paket-antirejderskih-zakoniv-uveresni.html. [Accessed 27.05.2019].

Verkhovna Rada of Ukraine (2001). Criminal Code of Ukraine. Available from: https://zakon.rada.gov.ua/laws/show/2341-14. [Accessed 27.05.2019].

Verkhovna Rada of Ukraine (2013). On Amendments to Certain Legislative Acts of Ukraine on Improving the Legal Regulation of the Activities of Legal Entities and Individual Entrepreneurs. Available from: https://zakon.rada.gov.ua/laws/show/642-18\#n46. [Accessed 28.05.2019].

Verkhovna Rada of Ukraine (2015). Law of Ukraine "On Amendments to the Law of Ukraine" On State Registration of Legal Entities and Individual Entrepreneurs "and some other legislative acts of Ukraine regarding the decentralization of powers of state registration of legal entities, individualsentrepreneurs and public formations". Available from: https://zakon.rada.gov.ua/laws/show/835-19\#n876. [Accessed 28.05.2019].

National Police: The notion of raiding is still not defined by law (2016). Available from: https://www.ukrinform.ua/rubric-society/2072225-nacpolicia-ponatta-rejderstva-dosi-ne-viznacenozakonom.html. [Accessed 03.06.2019].

Agrarian raiding Five meals before the intercessor of the Ministry of Justice. Available from: https://porady.org.ua/agrarne-reyderstvo-pyat-zapitan-do-zastupnika-ministra-yusticii. [Accessed 03.06.2019].

The anti-trader commission of the Ministry of Justice over 10 months of this year satisfied more than half a thousand complaints (2017). Available from: https://minjust.gov.ua/news/ministry/antireyderskakomisiva-minyustu-za-10-misvatsiv-tsogo-roku-zadovolnila-ponad-pivtisyachi-skarg. [Accessed 03.06.2019].

Verkhovna Rada of Ukraine (2016). On the activities of the Commission for the consideration of complaints in the field of state registration and the Commission on accreditation of subjects of state registration and monitoring compliance of such entities with the requirements for accreditation of January 12, 2016, No. 37/5. Available from: https://zakon.rada.gov.ua/laws/show/z0042-16. [Accessed 05.06.2019].

The farmer from Poltava region managed to win his land in the State Service of Ukraine for geodesy, cartography and cadastre (2019). Available from: https://agronews.ua/node/132303?fbclid=IwAR0uxHNnVPCibj_8GRZH1QMLEo1VrQXYzMfmfgB9eDX2J9IjLjKjIGYRVY. [Accessed 05.06.2019].

Raiding in Ukraine is a threat to national security (2010). Available from: http://veche.kiev.ua/journal/2105/. [Accessed 05.06.2019].

Price, raiding, cadastre, bargaining, gender: what else can be found in the database on land relations (2018). Available from: https://dankevychblog.wordpress.com/2018/06/24/price-raiding-cadastre-bargaininggender-what-else-can-be-found-in-the-database-on-landrelations/?fbclid=IwAR0y8wUCUz5S7Asap4ayCn1zQron43F7wVQlFI8QchnO-MN3fASqsX43Nos\#more347. [Accessed 05.06.2019].

Ukraine will develop a sustainable model of advisory services (2019). Available from: https://agronews.ua/node/131457? fbclid=IwAR3XWyMaZY9pBrnVQvfM796NufAWUWXsVhYnZ5c8VAdediz9ldxGieFbAY. [Accessed 05.06.2019].

The World Bank will provide Ukraine with a loan of $\$ 200$ million USA investment in agriculture (2019). Available from: https://www.growhow.in.ua/svitovyy-bank-nadast-ukraini-pozyku-u-rozmiri-200-mln-dolssha-na-investytsii-v-sil-s-ke-hospodarstvo/?fbclid=IwAR2y-V4fECMdXJi3nGCYlOp6GVMPH4owiem8Bv_-64dH9DBf5lwNFmse0Q. [Accessed 05.06.2019].

The main strategy of the UN for the next 10 years is the family farms (2019). Available from: https://agronews.ua/node/131168?fbclid=IwAR1JK9wrsZj5u8qKrcJ71 SG7jI9qUO5Y29P0Bjy nN8Jcha5PIE1tPXpQfQ. [Accessed 06.06.2019].

The Ministry of Agrarian Policy together with the EU Project is conducting a broad information campaign on state support to farmers (2019). Available from: https://minagro.gov.ua/ua/news/minagropolitikispilno-z-proektom-yes-provodyat-shiroku-informacijnu-kampaniyu-shchodo-derzhpidtrimkifermeriv?fbclid=IwAR07MY9gwW4z1KYaAG04ulLDYO8noYKeW6yGKC4AGKZgSKAJZ9 i53ZEPeY. [Accessed 06.06.2019].

The Committee on Agrarian Policy and Land Relations held a committee hearing on "small forms of management as a basis for sustainable rural development in the context of the implementation of the Association Agreement between Ukraine and the European Union" (2019). Available from: http://komagropolit.rada.gov.ua/news/main_news/73600.html?search=29\%20травня\%202019. [Accessed 06.06.2019]. 